\title{
PENERAPAN PEMBELAJARAN BERBASIS MASALAH MELALUI METODE EKSPERIMEN DAN DEMONSTRASI DITINJAU DARI KEMAMPUAN MENGGUNAKAN ALAT UKUR DAN SIKAP ILMIAH SISWA
}

\author{
Sodikin \\ Program Studi Pendidikan Fisika IAIN Raden Intan Lampung
}

Diterima: 5 Agustus 2015 Disetujui: 11 Oktober 2015. Dipublikasikan: Oktober 2015

\begin{abstract}
The purpose of this study is to know: the influence of experimental and demonstration learning methods to the learning achievement, the influence of the ability to use measuring tools, the influence of scientific attitude, the interaction between learning methods with the ability to use measuring instruments on learning achievement, (5) the interaction between learning methods with scientific attitude, the interaction between the ability to use a measuring instrument with a scientific attitude, the interaction between learning methods with the ability to use measuring tools and scientific attitudes. This research uses experimental method (experimental research). The study sample was determined randomly by technique cluster random sampling of two classes. Experiment 1 class with experiment method and experiment class 2 with demonstration method. Technique of collecting data using test method to get data of cognitive learning achievement and ability to use measuring instrument, whereas questionnaire method to get information of scientific attitude and affective learning achievement. The research hypothesis test using three way anova with 2x2x2 factorial design and cell frequency is not the same. From the result of the research, it can be concluded that: (1) There is no influence of the use of experimental and demonstration method to cognitive achievement ( $\mathrm{p}$-value $=0,151)$ and affective ( $\mathrm{p}$-value $=0,368)$. (2) There is no influence of ability to use measuring instrument to cognitive achievement ( $\mathrm{p}$-value $=0,593)$ and affective $(\mathrm{p}$-value $=726)$. (3) There is no influence of scientific attitude toward cognitive achievement ( $\mathrm{p}$-value $=0,399)$ and affective ( $\mathrm{p}$-value $=0,084)$. (4) There is no interaction between the learning method with the ability to use the measuring instrument to cognitive achievement ( $\mathrm{p}$ value $=0.832)$. (5) There is no interaction between learning method and scientific attitude toward cognitive achievement (p-value =0,839). (6) There is no interaction between the ability to use a measuring instrument with a scientific attitude toward cognitive achievement ( $\mathrm{p}$-value = 318). (7) There is an interaction between learning methods with the ability to use measuring tools and scientific attitudes toward cognitive achievement ( $\mathrm{p}$-value =0,029).
\end{abstract}

\begin{abstract}
Abstrak: Tujuan penelitian ini adalah untuk mengetahui: pengaruh metode pembelajaran eksperimen dan demonstrasi terhadap prestasi belajar, pengaruh kemampuan menggunakan alat ukur, pengaruh sikap ilmiah, interaksi antara metode pembelajaran dengan kemampuan menggunakan alat ukur terhadap prestasi belajar, (5) interaksi antara metode pembelajaran dengan sikap ilmiah, interaksi antara kemampuan menggunakan alat ukur dengan sikap ilmiah, interaksi antara metode pembelajaran dengan kemampuan menggunakan alat ukur dan sikap ilmiah. Penelitian ini menggunakan metode eksperimental (experimental research). Sampel penelitian ditentukan secara acak dengan teknik cluster random sampling sebanyak dua kelas. Kelas eksperimen 1 dengan metode eksperimen dan kelas eksperimen 2 dengan metode demonstrasi. Uji hipotesis penelitian menggunakan anava tiga jalan dengan desain faktorial $2 \times 2 \times 2$ dan frekuensi sel tidak sama. Dari hasil penelitian dapat disimpulkan bahwa: 1) Tidak ada pengaruh penggunaan metode pembelajaran eksperimen dan demonstrasi terhadap prestasi kognitif ( $p$-value $=0,151)$ dan afektif $(p$-value $=0,368) ; 2$ ) Tidak ada pengaruh kemampuan menggunakan alat ukur terhadap prestasi kognitif ( $p$-value $=$ 0,593) dan afektif ( $p$-value $=726) ; 3$ ) Tidak ada pengaruh sikap ilmiah terhadap prestasi kognitif ( $p$-value $=0,399)$ dan afektif ( $p$-value $=0,084) ; 4)$ Tidak ada interaksi antara metode pembelajaran dengan kemampuan menggunakan alat ukur terhadap prestasi kognitif ( $p$-value $=0,832)$; 5) Tidak ada interaksi antara metode pembelajaran dengan sikap ilmiah terhadap prestasi kognitif ( $p$-value $=0,839)$; 6) Tidak ada interaksi antara kemampuan menggunakan alat ukur dengan sikap ilmiah terhadap prestasi kognitif $(p$ value $=318)$; 7) Ada interaksi antara metode pembelajaran dengan kemampuan menggunakan alat ukur dan sikap ilmiah terhadap prestasi kognitif ( $p$-value $=0,029)$.
\end{abstract}

Kata kunci: metode eksperimen, metode demonstrasi, pembelajaran berbasis masalah, sikap ilmiah 


\section{PENDAHULUAN}

Orientasi pembelajaran fisika perlu lebih ditujukan kepada peran aktif siswa untuk belajar, sementara guru hanya sebagai fasilitator pembelajaran. Hal ini berarti harus ada pergeseran paradigma pembelajaran fisika, yakni dari yang semula guru menetapkan apa yang akan dipelajari (teacher centered) menjadi bagaimana menyediakan dan memperkaya pengalaman siswa (student centered). Pembelajaran fisika yang terjadi selama ini belum berorientasi pada student centered. Guru kurang memberi ruang kepada siswa untuk ikut serta aktif dalam mengemukakan pendapat. Akibatnya, siswa menjadi pasif dan kurang termotivasi untuk belajar fisika sehingga bagi sebagian siswa, fisika masih dianggap sebagai pelajaran yang sulit dan membosankan.

Berdasarkan uraian di atas, dapat dibuat konklusi bahwa untuk membelajarkan fisika sesuai dengan hakikat fisika yang sesungguhnya, yang meliputi proses, produk, dan sikap, maka diperlukan pendekatan pembelajaran yang tepat, inovatif, dan kreatif. Pendekatan pembelajaran yang tepat harus mampu membelajarkan siswa bagaimana cara memperoleh pengetahuan, bukan hanya menerima pengetahuan. Ada beberapa pendekatan pembelajaran fisika yang berorientasi pada proses. Pendekatan ini dapat digunakan oleh guru, antara lain: contextual teaching and learning (CTL) (Hutagaol, 2013; Saregar, et al, 2013), problem based learning (PBL) (Hung, Jonassen, \& Liu, 2008; Jonassen, \& Hung, 2008), Guided Inquiry (Kuhlthau, Maniotes \& Caspari, 2015; Bell, Urhahne, Schanze, \& Ploetzner, 2010), discovery learning (de Jong, \& Lazonder, 2014), dll. Meskipun telah banyak pendekatan pembelajaran fisika yang berorientasi pada proses dan sikap, namun pendekatan ini belum banyak diterapkan oleh para guru untuk membelajarkan fisika.

Pendekatan pembelajaran yang harus berorientasi pada proses, produk, dan sikap, diperlukan juga adanya metode pembelajaran yang berorientasi pada aktivitas siswa sehingga guru hanya berperan sebagai fasilitator saja. Metode pembelajaran yang dimaksud harus mampu membuat siswa aktif untuk mengiukuti proses pembelajaran fisika. Dengan demikian, siswa akan merasa mampu dan percaya diri terhadap pelajaran fisika. Beberapa metode pembelajaran yang mampu membuat siswa aktif, antara lain: metode eksperimen, demonstrasi, problem composing/making, peer tutoring (tutor sebaya), jigsaw, STAD, CBL, dll. Meskipun telah banyak metode pembelajaran fisika yang berorientasi pada aktivitas siswa, namun metode ini belum banyak digunakan oleh para guru untuk membelajarkan IPA, khususnya fisika.

Pendekatan dan metode pembelajaran fisika yang telah dijelaskan sebelumnya perlu lebih terfokus pada pemberian pengalaman belajar langsung kepada siswa. Guru sebagai fasilitator pembelajaran perlu menekankan pembelajaran bermakna bagi siswa. Jika penerapan pendekatan serta metode dalam pembelajaran fisika kurang tepat maka hal ini akan berakibat pada rendahnya prestasi belajar siswa, kurangnya motivasi siswa untuk mempelajari fisika, serta pembelajaran fisika menjadi tidak bermakna. Oleh karena itu, pemilihan pendekatan serta metode dalam pembelajaran fisika menjadi sesuatu yang sangat penting manakala tolok ukur keberhasilan pembelajaran tersebut kurang dapat menunjukkan hasil yang menggembirakan. Kenyataan yang terjadi, guru belum menggunakan modelmodel pembelajaran yang bervariatif dan 
inovatif sehingga masih terkesan konvensional dan monoton. Akibatnya, yang terjadi adalah prestasi belajar fisika siswa yang belum optimal dibandingkan dengan pelajaran yang lain. Hal tersebut yang akan menjadi perhatian serius dalam upaya meningkatkan prestasi belajar fisika siswa. Baik prestasi belajar kognitif yang berhubungan dengan pengetahuan dan pemahaman siswa, prestasi belajar afektif yang berkenaan dengan sikap dan kecakapan hidup seseorang, serta prestasi belajar psikomotor yang erat kaitannya dengan skill atau keterampilan seseorang.

Teori belajar bermakna Ausubel adalah proses belajar akan mendatangkan hasil atau bermakna jika guru dalam menyajikan materi pelajaran yang baru dapat menghubungkannya dengan konsep relevan yang sudah ada dalam struktur kognitif siswa. Hal tersebut berhubungan erat dengan kemampuan awal yang dimiliki siswa sebelum mempelajari konsep yang baru. Dengan kata lain, untuk mempelajari topik tertentu, siswa harus mempunyai kemampuan awal tertentu juga. Hal inilah yang harus diperhatikan oleh para guru dalam memulai proses pembelajaran fisika di kelas. Untuk memulai suatu topik dalam pelajaran fisika, guru hendaknya memperhatikan kemampuan awal yang dimiliki oleh peserta didik. Tujuannya yaitu untuk mempersiapkan guru dalam menyusun rancangan proses pembelajaran yang sesuai dengan tingkat kebutuhan siswa. Dengan demikian, proses pembelajaran di kelas akan lebih bermakna. Kemampuan awal siswa sebelum mempelajari materi tertentu dapat berupa kemampuan menggunakan alat ukur fisika yang berkaitan dengan materi tersebut. Hal inilah yang belum banyak diperhatikan oleh para guru.

Materi IPA, khususnya fisika, tidak dapat terlepas dari satu kesatuan yang terdiri atas proses, produk, dan sikap.
Proses sains dalam mempelajari IPA akan berjalan sesuai dengan kaidah yang benar manakala subjek yang melaksanakan proses tersebut memiliki sikap ilmiah yang memadai. Sikap ilmiah yakni suatu kecenderungan seseorang untuk berperilaku dan mengambil tindakan pemikiran ilmiah yang sesuai dengan metode ilmiah. Dalam lingkup yang lebih luas, sikap ilmiah menjadi ciri kompetensi seorang ilmuwan. Hal ini berarti bahwa seseorang dikatakan memiliki kompetensi seorang ilmuwan jika pada dirinya ditemukan sikap ilmiah sebagai cerminan dari penghayatannya terhadap proses dan produk sains. Dengan demikian, sikap ilmiah sangat penting untuk diperhatikan guru dalam mempelajari sains, khususnya fisika.

Selain faktor kemampuan awal dan sikap ilmiah siswa, masih ada beberapa faktor yang dapat mempengaruhi hasil prestasi belajar fisika siswa, antara lain: aktivitas belajar, gaya belajar, tingkat kecerdasan IQ, kreativitas, motivasi berprestasi siswa, dll. Meskipun faktorfaktor tersebut diketahui telah dapat mempengaruhi hasil prestasi belajar fisika siswa namun hal ini kurang dapat diperhatikan oleh para guru. Studi penelitian untuk mengetahui pengaruh faktor-faktor tersebut terhadap prestasi belajar fisika siswa juga masih perlu untuk ditingkatkan. Dengan demikian, penting bagi guru untuk memperhatikan faktor-faktor yang berpengaruh terhadap prestasi belajar fisika siswa untuk dapat mencapai tujuan pembelajaran yang diinginkan.

Memilih model pembelajaran yang tepat, guru harus memperhatikan kondisi siswa, sifat materi bahan ajar, dan fasilitas-media yang tersedia (Pepper 2008). Pendapat ini tentu saja tidak salah karena memang dalam membelajarkan konsep fisika yang kompleks, sangat penting bagi guru untuk memperhatikan sifat dan karakteristik materi bahan ajar 
yang akan disampaikan kepada siswa, apakah materi bahan ajar tersebut bersifat konkret atau abstrak. Untuk menyampaikan materi bahan ajar fisika yang bersifat konkret, tentu saja diperlukan pendekatan dan metode yang berbeda dengan yang abstrak. Piaget dalam (Suparno, 2007) menyatakan bahwa "pengetahuan yang akurat terhadap suatu objek tidak dapat diperoleh dari membaca, melihat gambar, mendengarkan orang bicara, tetapi hanya dapat diperoleh melalui campur tangan siswa terhadap objek tersebut". Objek itulah yang akan membiarkan siswa untuk mengerti sifat-sifatnya. Dari pernyataan tersebut, jelas bahwa untuk membelajarkan konsep fisika yang konkret diperlukan pendekatan dan metode pembelajaran yang dapat memberikan pengalaman belajar langsung kepada siswa lewat interaksinya terhadap lingkungan. Dengan demikian, penting bagi guru untuk mengetahui sifat dan karakteristik materi bahan ajar, sebelum menentukan pendekatan dan metode pembelajaran yang sesuai dengan materi yang akan disampaikan kepada siswa. Namun demikian, sebagian guru masih belum memperhatikan sifat dan karakteristik materi bahan ajar fisika dalam menentukan pendekatan dan metode pembelajaran yang sesuai.

Materi bahan ajar fisika yang disampaikan di kelas XI IPA antara lain: gerak lurus beraturan (GLB), gerak lurus berubah beraturan (GLBB), gerak parabola, gerak melingkar, hukum Newton tentang gravitasi, hukum Hooke dan elastisitas, osilasi (getaran), usaha dan energi, hukum kelestarian energi mekanik, momentum, impuls, dan tumbukan. Materi hukum Hooke dan elastisitas merupakan salah satu materi fisika yang bersifat konkret. Maksudnya adalah untuk membelajarkan konsep elastisitas diperlukan pengalaman langsung siswa terhadap objek atau benda-benda yang berkaitan dengan materi tersebut. Tujuannya adalah agar siswa sendiri yang membangun konsep tentang materi tersebut dari interaksinya terhadap objek dan lingkungan. Selain itu, siswa juga diharapkan mampu mengaplikasikan apa yang telah diperolehnya dalam kehidupan seharihari. Dengan demikian, hasil belajar yang dicapai tentunya dapat lebih bermakna dan siswa mempunyai tujuan yang nyata dalam mengikuti pembelajaran. Namun, guru belum menyampaikan konsep materi tersebut secara bermakna kepada siswa.

Kesimpulan dari uraian di atas adalah untuk mengatasi masalah pembelajaran yang kompleks, diperlukan suatu pendekatan dan metode pembelajaran yang mampu mengatasi, minimal dapat mengurangi, masalah pembelajaran yang ada. Salah satu pendekatan pembelajaran yang dapat digunakan adalah Problem Based Learning (PBL). PBL merupakan salah satu pembelajaran inovatif yang dapat memberikan kondisi belajar aktif kepada siswa. PBL melalui metode eksperimen dan demonstrasi lebih berpusat pada siswa dan memberi kesempatan kepada siswa untuk terlibat secara langsung dalam proses: mengamati, menafsirkan pengamatan, meramalkan, menggunakan alat dan bahan, menemukan konsep, merencanakan penelitian, berkomunikasi dan mengajukan pertanyaan. Melalui PBL diharapkan prestasi belajar fisika siswa dapat lebih baik dan meningkat. Hal tersebut mengacu pada hasil penelitian yang dilakukan oleh (Johannes Strobel \& Angela van Barneveld 2009: 53-55) yang menyatakan bahwa siswa yang diajar dengan PBL mengungguli siswa yang diajarkan dengan cara tradisional. Secara keseluruhan, siswa dan staf (guru) menunjukkan kepuasan yang lebih besar dengan model PBL. Hasil penelitian tersebut juga 
menunjukkan bahwa PBL lebih efektif jika diterapkan pada siswa dengan retensi atau memori jangka panjang serta berfokus pada kinerja dan berorientasi pada keterampilan.

PBL yang dijadikan sebagai fokus pembelajaran dapat dilakukan siswa melalui kerja kelompok sehingga dapat memberi pengalaman-pengalaman belajar yang beragam pada siswa seperti kerjasama dan interaksi dalam kelompok, disamping pengalaman belajar yang berhubungan dengan inquiry, seperti membuat hipotesis, merancang percobaan, melakukan penyelidikan, mengumpulkan data, menginterpretasikan data, membuat kesimpulan, dan membuat laporan. Keadaan tersebut dapat memberikan pengalaman yang kaya kepada siswa. Dengan kata lain, PBL dapat meningkatkan pemahaman siswa tentang apa yang mereka pelajari sehingga diharapkan mereka dapat menerapkannya dalam kondisi nyata dalam kehidupan sehari-hari.

Model PBL yang diangkat sebagai tema dalam penelitian ini salah satu tujuannya yaitu sebagai khazanah untuk meramaikan penelitian, khususnya penelitian dalam dunia pendidikan. Hal ini sesuai dengan hasil penelitian dan rekomendasi yang dilakukan oleh Andrew (Walker \& Heather Leary, 2009), menyatakan bahwa disiplin studi dalam bidang pendidikan yang dilakukan oleh guru menunjukkan hasil yang cukup baik dibandingkan dengan disiplin studi yang lain, seperti teknik, ilmu pengetahuan (science), pendidikan medis, dll. Hasil penelitian tersebut kemudian memberikan rekomendasi kepada para peneliti atau praktisi pendidikan bahwa PBL sebagai suatu model pembelajaran harus lebih banyak dilakukan dan dikembangkan dalam bidang pendidikan, khususnya yang dilakukan oleh guru. Hal tersebut dikarenakan bidang pendidikan merupakan bidang yang paling menjanjikan diantara bidang yang lain.

\section{METODE PENELITIAN}

Penelitian ini dilaksanakan di SMA negeri 12 Bandar lampung. Waktu pelaksanaannya pada semester I tahun pelajaran 2012/2013. Penelitian ini termasuk dalam jenis penelitian kuasi eksperimen. Variabel terikat penelitian ini adalah prestasi belajar siswa. Variabel bebas adalah model PBL dengan metode eksperimen dan demonstrasi. Sebagai variabel moderator kemampuan menggunakan alat ukur dan sikap ilmiah.

Populasi dalam penelitian ini adalah seluruh siswa kelas XI SMA Negeri 12 Bandar lampung tahun pelajaran 2012/2013 yang terdiri dari 8 kelas program IPA dengan jumlah siswa sebanyak 244 siswa. Pada penelitian ini, kemampuan menggunakan alat ukur dikategorikan menjadi tinggi dan rendah. Sikap ilmiah siswa dikategorikan menjadi sikap ilmiah tinggi dan rendah. Berkaitan dengan hal tersebut maka rancangan data penelitian ini dapat disajikan dalam desain faktorial $2 \times 2 \times 2$ dengan teknik analisis varians (Anava). Teknik pengumpulan data dalam penelitian ini menggunakan: 1) teknik tes digunakan untuk mengetahui tingkat kemampuan siswa dalam menggunakan alat ukur fisika yang dikategorikan tinggi dan rendah. Selain itu, metode tes ini juga digunakan untuk memperoleh data prestasi belajar fisika siswa pada ranah kognitif.; 2) teknik angket digunakan untuk mengetahui sikap ilmiah dan prestasi belajar fisika siswa pada ranah afektif. Bentuk angket yang digunakan berupa angket tertutup dengan empat alternatif jawaban. Sebelum angket ini digunakan untuk mengambil data penelitian, terlebih dahulu angket diujicobakan untuk mengetahui validitas dan reliabilitas angket. 
Instrumen pelaksanaan penelitian yang digunakan berupa silabus, rencana pelaksanaan pembelajaran (RPP), lembar kerja siswa (LKS). Uji normalitas yang digunakan adalah uji Kosmogorov Samirnov dan uji homogenitas digunakan adalah uji Levene's. Hipotesis dalam penelitian ini diuji dengan menggunakan uji Anava. Semua uji dilakukan menggunakan software PASW statistic18.

\section{HASIL DAN PEMBAHASAN}

\section{Analisis Variansi Prestasi Kognitif}

Uji hipotesis dalam penelitian ini menggunakan anava tiga jalan karena faktor yang terlibat dan bertindak sebagai variabel bebas ada tiga faktor, yaitu metode pembelajaran, kemampuan menggunakan alat ukur fisika, dan sikap ilmiah siswa. Adapun ringkasan hasil analisis variansi tiga jalan dengan frekuensi sel tidak sama dapat dicermati pada tabel 1 .

Tabel 1. Ringkasan anava tiga jalan prestasi kognitif

\begin{tabular}{cccc}
\hline No. & $\begin{array}{c}\text { Sumber } \\
\text { Variansi }\end{array}$ & p-value & Keputusan Uji \\
\hline 1. & A & 0,151 & $\begin{array}{c}\mathrm{H}_{01} \text { tidak } \\
\text { ditolak }\end{array}$ \\
\hline 2. & B & 0,593 & $\begin{array}{c}\mathrm{H}_{02} \text { tidak } \\
\text { ditolak }\end{array}$ \\
\hline 3. & C & 0,399 & $\begin{array}{c}\mathrm{H}_{03} \text { tidak } \\
\text { ditolak }\end{array}$ \\
\hline 4. & AB & 0,832 & $\begin{array}{c}\mathrm{H}_{012} \text { tidak } \\
\text { ditolak }\end{array}$ \\
\hline 5. & AC & 0,839 & $\begin{array}{c}\mathrm{H}_{013} \text { tidak } \\
\text { ditolak }\end{array}$ \\
\hline 6. & BC & 0,318 & $\begin{array}{c}\mathrm{H}_{023} \text { tidak } \\
\text { ditolak }\end{array}$ \\
\hline 7. & ABC & 0,029 & $\mathrm{H}_{0123}$ ditolak \\
\hline
\end{tabular}

Hasil tersebut digunakan sebagai dasar pengambilan keputusan penolakan hipotesis penelitian sebagai berikut:

a. $\mathrm{H}_{01}$ : Tidak ada pengaruh penggunaan pendekatan PBL melalui metode eksperimen dan demonstrasi terhadap prestasi kognitif siswa. Hipotesis $\mathrm{H}_{01}$ ini tidak ditolak karena $p$-value $=$ $0,151>\alpha=0,05$.

b. $\mathrm{H}_{02}$ : Tidak ada pengaruh kemampuan menggunakan alat ukur kategori tinggi dan kemampuan menggunakan alat ukur kategori rendah terhadap prestasi kognitif siswa. Hipotesis $\mathrm{H}_{02}$ ini tidak ditolak karena $p$-value $=$ $0,593>\alpha=0,05$.

c. $\mathrm{H}_{03}$ : Tidak ada pengaruh sikap ilmiah tinggi dan sikap ilmiah rendah terhadap prestasi kognitif siswa. Hipotesis $\mathrm{H}_{03}$ ini tidak ditolak karena $p$-value $=0,399>\alpha=0,05$.

d. $\mathrm{H}_{012}$ : Tidak ada interaksi antara metode pembelajaran dengan kemampuan menggunakan alat ukur terhadap prestasi kognitif siswa. Hipotesis $\mathrm{H}_{012}$ ini tidak ditolak karena $p$-value $=0,832>\alpha=0,05$.

e. $\mathrm{H}_{013}$ : Tidak ada interaksi antara metode pembelajaran dengan sikap ilmiah siswa terhadap prestasi kognitif siswa. Hipotesis $\mathrm{H}_{013}$ ini tidak ditolak karena $p$-value $=0,839$ $>\alpha=0,05$.

f. $\mathrm{H}_{023}$ : Tidak ada interaksi antara kemampuan menggunakan alat ukur dengan sikap ilmiah siswa terhadap prestasi kognitif siswa. Hipotesis $\mathrm{H}_{023}$ ini tidak ditolak karena $p$-value $=$ $0,318>\alpha=0,05$.

g. H0123: Tidak ada interaksi antara metode pembelajaran dengan kemampuan menggunakan alat ukur dan sikap ilmiah siswa terhadap prestasi kognitif siswa. Hipotesis $\mathrm{H}_{0123}$ ini ditolak karena $p$-value $=$ $0,029<\alpha=0,05$.

Ketentuan untuk menolak $\mathrm{H}_{0}$ dalam penelitian ini adalah jika $p$-value lebih kecil dibandingkan dengan nilai taraf signifikansi $\alpha=0,05$. Hasil perhitungan anava tiga jalan dengan menggunakan program minitab seri 15 pada tabel 4.10 di atas menunjukkan bahwa semua $p$ value bernilai lebih besar dari taraf signifikansi $\alpha$, kecuali untuk hipotesis ketujuh, yakni adanya interaksi antara 
metode pembelajaran dengan kemampuan menggunakan alat ukur dan sikap ilmiah siswa terhadap prestasi kognitif siswa. Hasil perhitungan yang ditampilkan pada tabel di atas menunjukkan bahwa p-value untuk hipotesis ketujuh nilainya lebih kecil dibandingkan dengan nilai taraf signifikansi $\alpha$ sehingga $\mathrm{H}_{0123}$ ditolak. Dengan demikian, hanya hipotesis ketujuh saja yang selanjutnya dapat diuji lanjut anava.

\section{Uji Lanjut Analisis Variansi Tiga Jalan}

Uji lanjut anava atau uji komparasi ganda diperlukan untuk mengetahui karakteristik hubungan antara variabel bebas dengan variabel terikat. Uji lanjut anava hanya dilakukan pada $\mathrm{H}_{0}$ yang ditolak, yaitu dengan cara membandingkan rerata dengan uji komparasi ganda Scheffe. Dari hasil perhitungan anava tiga jalan pada tabel 1 di atas, hipotesis yang perlu diuji lebih lanjut adalah hipotesis $\mathrm{H}_{0123}$, yaitu "ada interaksi antara metode pembelajaran dengan kemampuan menggunakan alat ukur dan sikap ilmiah siswa terhadap prestasi kognitif siswa". Adapun hasil uji lanjut untuk mengetahui bagaimana interaksi antara metode pembelajaran dengan kemampuan menggunakan alat ukur dan sikap ilmiah siswa terhadap prestasi kognitif siswa,

\section{Analisis Prestasi Afektif}

Berdasarkan hasil uji prasyarat analisis varians, diketahui bahwa ternyata data prestasi siswa pada aspek afektif berdistribusi normal namun tidak memenuhi syarat homogenitas. Oleh karena itu, data prestasi afektif tersebut sebagai alternatif pengujiannya dilakukan dengan metode Kruskal-Wallis, yaitu uji statistik nonparametrik yang mendasarkan pada median data, bukan pada mean (rerata) data seperti pada uji Anava dan uji statistik parametrik lainnya. Tabel 2 merupakan ringkasan hasil uji Kruskal-Wallis untuk ranah afektif dengan faktor penguji metode pembelajaran, kemampuan menggunakan alat ukur, dan sikap ilmiah siswa.

Tabel 2. Ringkasan uji Kruskal-Wallis prestasi afektif

\begin{tabular}{lccc}
\hline No. & $\begin{array}{c}\text { Sumber } \\
\text { Varians }\end{array}$ & p-value & Keputusan Uji \\
\hline 1. & $\mathrm{A}$ & 0,368 & $\mathrm{H}_{01}$ tidak ditolak \\
\hline 2. & $\mathrm{~B}$ & 0,726 & $\mathrm{H}_{02}$ tidak ditolak \\
\hline 3. & $\mathrm{C}$ & 0,084 & $\mathrm{H}_{03}$ tidak ditolak \\
\hline
\end{tabular}

Hasil uji Kruskal-Wallis pada tabel di atas dapat digunakan sebagai acuan penolakan hipotesis sebagai berikut:

a. $\mathrm{H}_{01}$ : Tidak ada pengaruh penggunaan pendekatan PBL melalui metode eksperimen dan demonstrasi terhadap prestasi afektif siswa. Hipotesis $\mathrm{H}_{01}$ ini tidak ditolak karena $p$-value $=$ $0,368>\alpha=0,05$.

b. $\mathrm{H}_{02}$ : Tidak ada pengaruh kemampuan menggunakan alat ukur kategori tinggi dan kemampuan menggunakan alat ukur kategori rendah terhadap prestasi afektif siswa. Hipotesis $\mathrm{H}_{02}$ ini tidak ditolak karena $p$-value $=$ $0,726>\alpha=0,05$.

c. $\mathrm{H}_{03}$ : Tidak ada pengaruh sikap ilmiah tinggi dan sikap ilmiah rendah terhadap prestasi afektif siswa. Hipotesis $\mathrm{H}_{03}$ ini tidak ditolak karena $p$-value $=0,084>\alpha=0,05$.

Salah satu kelemahan dari uji statistik nonparametrik untuk mengolah data penelitian adalah uji ini tidak mampu mengukur adanya interaksi antar faktor atau antar variabel bebas terhadap variabel terikatnya. Uji ini hanya dapat mengukur pengaruh variabel bebas terhadap variabel terikatnya sehingga hipotesis yang dapat dibuktikan dengan uji Kruskal-Wallis ini hanya hipotesis pertama, kedua, dan ketiga saja. Dengan demikian, hipotesis keempat sampai dengan ketujuh tidak dapat dibuktikan dengan metode statistik nonparametrik Kruskal-Wallis ini. 


\section{Pembahasan Hasil Analisis Data Prestasi Kognitif \\ a. Hipotesis Pertama}

Dari hasil analisis data menggunakan anava tiga jalan diperoleh p-value metode pembelajaran sebesar 0,151. P-value ini jelas lebih besar dibandingkan dengan nilai taraf signifikansi $\alpha$ yang telah ditetapkan sebelumnya, yakni sebesar 0,05 atau $5 \%$. Dengan demikian, hipotesis nol pertama $\left(\mathrm{H}_{01}\right)$ yang menyatakan bahwa tidak ada pengaruh penggunaan pendekatan PBL melalui metode eksperimen dan demonstrasi terhadap prestasi kognitif siswa, tidak ditolak. Hal ini berarti bahwa antara metode pembelajaran eksperimen dan demonstrasi tidak memiliki pengaruh yang signifikan terhadap prestasi belajar siswa aspek kognitif pada pokok bahasan hukum Hooke dan elastisitas. Hal ini disebabkan karena metode eksperimen yang digunakan tidak dengan inquiry dan masih bersifat konvensional. Siswa hanya diminta untuk melakukan kegiatan sesuai dengan apa yang terdapat pada LKS sehingga siswa tidak dituntut untuk kritis. Akibatnya, prestasi belajar siswa belum menunjukkan hasil yang memuaskan. Namun jika ditinjau dari aktivitas belajar, maka siswa yang dibelajarkan dengan metode eksperimen menunjukkan aktivitas dan motivasi yang lebih baik jika dibandingkan dengan metode demonstrasi. Hal ini disebabkan oleh siswa yang dibelajarkan dengan metode eksperimen dituntut untuk mampu melakukan dan menyusun sendiri alatalat percobaan yang akan digunakan, serta dapat mengulangi percobaan jika hasilnya belum memuaskan. Hasil penelitian ini menunjukkan bahwa kedua metode pembelajaran tersebut sama baiknya digunakan pada proses pembelajaran fisika untuk memecahkan masalah (Problem Based Learning), khususnya pada pokok bahasan hukum Hooke dan elastisitas. Dengan demikian, pendekatan Problem Based Learning (PBL) akan menghasilkan prestasi belajar yang sama baiknya jika diajarkan dengan metode eksperimen maupun demonstrasi pada pokok bahasan hukum Hooke dan elastisitas.

\section{b. Hipotesis Kedua}

Harga $p$-value untuk hipotesis nol yang kedua $\left(\mathrm{H}_{02}\right)$ adalah sebesar 0,593 . Nilai ini jauh lebih besar jika dibandingkan dengan harga taraf signifikansi $\alpha$ yang telah ditetapkan sebelumnya, yakni sebesar 0,05 . Hal ini menunjukkan bahwa hipotesis nol yang kedua $\left(\mathrm{H}_{02}\right)$ tidak ditolak, yang berarti tidak ada pengaruh kemampuan menggunakan alat ukur kategori tinggi dan rendah terhadap prestasi kognitif siswa. Tabel 2 menunjukkan deskripsi data prestasi kognitif siswa berdasarkan kemampuan menggunakan alat ukur. Kelompok siswa dengan kemampuan menggunakan alat ukur kategori tinggi memiliki rerata prestasi kognitif $(\bar{x})$ sebesar 61,67 sedangkan kelompok siswa dengan kemampuan menggunakan alat ukur kategori rendah memiliki rerata prestasi kognitif $(\bar{x})$ sebesar 62,44. Sementara itu, standar deviasi (SD) dari data prestasi kognitif pada siswa dengan kemampuan menggunakan alat ukur kategori tinggi adalah sebesar 11,38 sedangkan pada siswa dengan kemampuan menggunakan alat ukur kategori rendah adalah sebesar 9,30. Selanjutnya, kesalahan relatif dari masing-masing kelompok diperoleh prosentase kesalahan pada siswa dengan kemampuan menggunakan alat ukur kategori tinggi adalah sebesar 18,45\% sedangkan pada siswa dengan kemampuan menggunakan alat ukur kategori rendah adalah sebesar 14,89\%. Makna dari nilai $18,45 \%$ adalah jika dilakukan penelitian dengan 100 kali pengambilan data maka ada kemungkinan terjadi kesalahan sebanyak 18 kali, begitu juga dengan nilai $14,89 \%$. 
Semakin kecil prosentase kesalahan penelitian, maka semakin baik hasil penelitian tersebut. Karena prosentase kesalahan pada kelompok siswa dengan kemampuan menggunakan alat ukur kategori rendah lebih kecil dibandingkan dengan kategori tinggi maka prestasi kognitif siswa dengan kemampuan menggunakan alat ukur kategori rendah lebih baik dibandingkan dengan kategori tinggi.

Tabel 3. Data prestasi kognitif ditinjau dari kemampuan menggunakan alat ukur

\begin{tabular}{|c|c|c|}
\hline No & Komponen & $\begin{array}{l}(\mathrm{N} ; \bar{x} ; \mathrm{SD} ; \\
\text { min; maks) }\end{array}$ \\
\hline 1. & $\begin{array}{l}\text { Kemampuan } \\
\text { Menggunakan Alat } \\
\text { Ukur Kategori Tinggi } \\
\text { (B1) }\end{array}$ & $\begin{array}{c}34 ; 61,67 ; \\
11,38 ; 40,00 ; \\
90,00\end{array}$ \\
\hline 2. & $\begin{array}{l}\text { Kemampuan } \\
\text { Menggunakan Alat } \\
\text { Ukur Kategori Rendah } \\
\text { (B2) }\end{array}$ & $\begin{array}{c}30 ; 62,44 \\
9,30 ; 40,00 \\
83,33\end{array}$ \\
\hline
\end{tabular}

\section{c. Hipotesis Ketiga}

Berdasarkan perhitungan dengan anava, diperoleh $p$-value untuk hipotesis nol yang ketiga $\left(\mathrm{H}_{03}\right)$ sebesar 0,399 . Hasil ini jauh lebih besar jika dibandingkan dengan nilai taraf signifikansi $\alpha$ yang telah ditetapkan sebelumnya, yakni sebesar 0,05. Hal ini menunjukkan bahwa hipotesis nol yang ketiga $\left(\mathrm{H}_{03}\right)$ tidak ditolak, yang berarti tidak ada pengaruh sikap ilmiah tinggi dan sikap ilmiah rendah terhadap prestasi kognitif siswa. Tidak adanya pengaruh sikap ilmiah tinggi dan sikap ilmiah rendah terhadap prestasi kognitif siswa mungkin disebabkan karena instrumen pengambilan data untuk memperoleh informasi tentang sikap ilmiah siswa hanya diperoleh dari angket saja. Adapun salah satu kelemahan angket sebagai instrumen pengambilan data adalah bersifat subjektif atau hanya berdasar pada pengakuan sepihak saja dari siswa sehingga data sikap ilmiah yang diperoleh kurang akurat dan kurang dapat dipercaya. Dengan demikian, untuk memperoleh informasi tentang sikap ilmiah yang lebih valid dari siswa, sebaiknya selain adanya angket perlu juga adanya observasi secara langsung dan interview pada siswa.

Tabel 4. Data prestasi kognitif ditinjau dari sikap ilmiah

\begin{tabular}{lll}
\hline No. & Komponen & $(\mathbf{N} ; \overline{\boldsymbol{x}} ; \mathbf{S D} ; \mathbf{m i n} ; \mathbf{m a k s})$ \\
\hline \multirow{2}{*}{ 1. } & Sikap Ilmiah & $26 ; 63,21 ; 9,73 ; 40,00 ;$ \\
& Tinggi $(\mathrm{C} 1)$ & 83,33 \\
\hline \multirow{2}{*}{ 2. } & Sikap Ilmiah & $38 ; 61,23 ; 10,86 ;$ \\
& Rendah $(\mathrm{C} 2)$ & 40,$00 ; 90,00$ \\
\hline
\end{tabular}

Berdasarkan tabel 4 menunjukkan deskripsi data prestasi kognitif siswa berdasarkan sikap ilmiah siswa. Kelompok siswa dengan sikap ilmiah tinggi memiliki rerata prestasi kognitif $(\bar{x})$ sebesar 63,21 sedangkan kelompok siswa dengan sikap ilmiah rendah memiliki rerata prestasi kognitif $(\bar{x})$ sebesar 61,23. Sementara itu, standar deviasi (SD) dari data prestasi kognitif pada siswa dengan sikap ilmiah tinggi adalah sebesar 9,73 sedangkan pada siswa dengan sikap ilmiah rendah adalah sebesar 10,86. Kesalahan relatif dari masing-masing kelompok diperoleh prosentase kesalahan pada siswa dengan sikap ilmiah tinggi adalah sebesar $15,39 \%$ sedangkan pada siswa dengan sikap ilmiah rendah adalah sebesar $17,74 \%$.

Makna dari nilai $15,39 \%$ adalah jika dilakukan penelitian dengan 100 kali pengambilan data maka ada kemungkinan terjadi kesalahan sebanyak 15 kali, begitu juga dengan nilai 17,74\%. Semakin kecil prosentase kesalahan penelitian, maka semakin baik hasil penelitian tersebut. Karena prosentase kesalahan pada kelompok siswa dengan sikap ilmiah tinggi lebih kecil dibandingkan dengan sikap ilmiah rendah maka prestasi kognitif siswa dengan 
sikap ilmiah tinggi lebih baik dibandingkan dengan sikap ilmiah rendah.

\section{d. Hipotesis Keempat}

Hasil analisa data dari uji hipotesis yang pertama dan kedua menunjukkan bahwa tidak ada pengaruh penggunaan metode pembelajaran terhadap prestasi kognitif siswa dan tidak ada pengaruh kemampuan awal siswa terhadap prestasi kognitifnya. Hasil analisis data dengan anava di atas menunjukkan bahwa $p$ value untuk hipotesis nol yang keempat $\left(\mathrm{H}_{012}\right)$ sebesar 0,832 . Hasil ini jauh lebih besar jika dibandingkan dengan nilai taraf signifikansi $\alpha$ yang telah ditetapkan sebelumnya, yakni sebesar 0,05 . Hal ini menunjukkan bahwa hipotesis nol yang keempat $\left(\mathrm{H}_{012}\right)$ tidak ditolak, yang berarti tidak ada interaksi antara metode pembelajaran dengan kemampuan awal siswa terhadap prestasi kognitif siswa. Berdasarkan tabel 5, tidak adanya interaksi ini disebabkan oleh prosentase kesalahan pada masing-masing sel lebih besar dari $5 \%$. Siswa yang dibelajarkan dengan metode eksperimen dengan kemampuan menggunakan alat ukur kategori tinggi prosentase kesalahannya sebesar 14,86\% dan kategori rendah prosentase kesalahannya sebesar $14,47 \%$. Sedangkan siswa yang dibelajarkan dengan metode demonstrasi dengan kemampuan menggunakan alat ukur kategori tinggi prosentase kesalahannya sebesar 21,48\% dan kategori rendah prosentase kesalahannya sebesar $15,78 \%$. (Wawan, 2007) siswa yang memiliki kemampuan menggunakan alat ukur kategori tinggi maupun rendah, keduanya akan memiliki prestasi kognitif yang lebih baik jika dibelajarkan dengan metode eksperimen.

Tabel 5. Data prestasi kognitif ditinjau dari metode dan kemampuan menggunakan alat ukur

\begin{tabular}{|c|c|c|}
\hline & \multicolumn{2}{|c|}{ Metode (A) } \\
\hline & $\begin{array}{c}\text { Eksperimen } \\
\quad(\mathrm{A} 1) \\
(\mathrm{N} ; \bar{x} ; \mathrm{SD} ; \\
\text { min; maks) }\end{array}$ & $\begin{array}{c}\text { Demonstrasi } \\
(\mathrm{A} 2) \\
(\mathrm{N} ; \bar{x} ; \mathrm{SD} ; \\
\text { min; maks) }\end{array}$ \\
\hline $\begin{array}{l}\text { Kemampuan } \\
\text { Menggunakan } \\
\text { Alat Ukur } \\
\text { Kategori Tinggi } \\
\text { (B1) }\end{array}$ & $\begin{array}{l}17 ; 64,31 ; \\
9,56 ; 46,67 ; \\
76,67\end{array}$ & $\begin{array}{l}17 ; 59,02 ; \\
12,68 ; \\
40,00 ; 90,00\end{array}$ \\
\hline $\begin{array}{l}\text { Kemampuan } \\
\text { Menggunakan } \\
\text { Alat Ukur } \\
\text { Kategori } \\
\text { Rendah (B2) }\end{array}$ & $\begin{array}{l}15 ; 63,11 ; \\
9,13 ; 50,00 ; \\
83,33\end{array}$ & $\begin{array}{l}15 ; 61,78 ; \\
9,75 ; 40,00 \\
73,33\end{array}$ \\
\hline
\end{tabular}

\section{e. Hipotesis Kelima}

Hasil analisis data dengan anava sebelumnya menunjukkan bahwa $p$-value untuk hipotesis nol yang kelima $\left(\mathrm{H}_{013}\right)$ sebesar 0,839 . Hasil ini jauh lebih besar jika dibandingkan dengan nilai taraf signifikansi $\alpha$ yang telah ditetapkan sebelumnya, yakni sebesar 0,05 . Hal ini menunjukkan bahwa hipotesis nol yang kelima $\left(\mathrm{H}_{013}\right)$ tidak ditolak, yang berarti tidak ada interaksi antara metode pembelajaran dengan sikap ilmiah siswa terhadap prestasi kognitif siswa. Berdasarkan tabel 6, tidak adanya interaksi ini disebabkan oleh prosentase kesalahan pada masing-masing sel lebih besar dari $5 \%$. Siswa yang dibelajarkan dengan metode eksperimen yang memiliki sikap ilmiah tinggi prosentase kesalahannya sebesar $15,92 \%$ dan siswa dengan sikap ilmiah rendah prosentase kesalahannya sebesar 13,66\%. Sedangkan siswa yang dibelajarkan dengan metode demonstrasi yang memiliki sikap ilmiah tinggi prosentase kesalahannya sebesar 14,93 dan siswa dengan sikap ilmiah rendah prosentase kesalahannya sebesar $21,40 \%$. Dari hasil tersebut, dapat disarankan bahwa siswa yang memiliki sikap ilmiah tinggi lebih 
baik dibelajarkan dengan metode demonstrasi, sedangkan siswa yang memiliki sikap ilmiah rendah lebih baik jika dengan metode eksperimen.

Tabel 6. Data prestasi kognitif ditinjau dari metode dan sikap ilmiah

\begin{tabular}{|c|c|c|c|c|}
\hline \multirow[b]{3}{*}{$\begin{array}{l}\text { Sikap } \\
\text { Ilmiah } \\
\text { Tinggi } \\
\text { (C1) }\end{array}$} & \multicolumn{4}{|c|}{ Metode (A) } \\
\hline & \multicolumn{2}{|c|}{$\begin{array}{c}\text { Eksperimen } \\
(\mathrm{A} 1) \\
(\mathrm{N} ; \bar{x} ; \mathrm{SD} ; \\
\text { min; maks) }\end{array}$} & \multicolumn{2}{|c|}{$\begin{array}{c}\text { Demonstrasi } \\
(\mathrm{A} 2) \\
(\mathrm{N} ; \bar{x} ; \mathrm{SD} ; \\
\text { min; maks) }\end{array}$} \\
\hline & $\begin{array}{l}13 ; \\
10,33 ; \\
83,33\end{array}$ & $\begin{array}{l}64,87 \\
46,67\end{array}$ & $\begin{array}{l}13 ; \\
9,19 \\
73,33\end{array}$ & $\begin{array}{l}61,54 \\
40,00\end{array}$ \\
\hline $\begin{array}{l}\text { Sikap } \\
\text { Ilmiah } \\
\text { Rendah } \\
\text { (C2) }\end{array}$ & $\begin{array}{l}19 ; \\
8,60 \\
76,67\end{array}$ & $\begin{array}{l}62,98 \\
46,67 ;\end{array}$ & $\begin{array}{l}19 ; \\
12,73 ; \\
90,00\end{array}$ & $\begin{array}{l}59,47 \\
40,00\end{array}$ \\
\hline
\end{tabular}

\section{f. Hipotesis Keenam}

Hasil analisis data dengan anava sebelumnya menunjukkan bahwa $p$-value untuk hipotesis nol yang keenam $\left(\mathrm{H}_{023}\right)$ sebesar 0,318. Hasil ini lebih besar jika dibandingkan dengan nilai taraf signifikansi $\alpha$ yang telah ditetapkan sebelumnya, yakni sebesar 0,05 . Hal ini menunjukkan bahwa hipotesis nol yang keenam $\left(\mathrm{H}_{023}\right)$ tidak ditolak, yang berarti tidak ada interaksi antara kemampuan awal dengan sikap ilmiah siswa terhadap prestasi kognitif siswa. Hasil ini merupakan konsekuensi dari dua keputusan sebelumnya, yaitu secara parsial kemampuan awal siswa tidak berpengaruh secara signifikan terhadap prestasi belajar pada aspek kognitif, dan sikap ilmiah siswa juga tidak berpengaruh secara signifikan terhadap prestasi kognitifnya. Berdasarkan tabel 7 , tidak adanya interaksi ini disebabkan oleh prosentase kesalahan pada masingmasing sel lebih besar dari 5\%. Siswa yang memiliki kemampuan menggunakan alat ukur kategori tinggi dan sikap ilmiah tinggi prosentase kesalahannya sebesar $13,54 \%$, sedangkan siswa yang memiliki kemampuan menggunakan alat ukur kategori tinggi dan sikap ilmiah rendah. (Dwijananti, \& Yulianti, 2010), kebiasaan berpikir kritis dalam menanggapi fenomena alam dengan menggunakan metode ilmiah. Siswa yang memiliki kemampuan menggunakan alat ukur kategori rendah dan sikap ilmiah tinggi prosentase kesalahannya sebesar $17,29 \%$, sedangkan siswa yang memiliki kemampuan menggunakan alat ukur kategori rendah dan sikap ilmiah rendah prosentase kesalahannya sebesar $12,56 \%$.

Tabel 7. Data prestasi kognitif ditinjau dari kemampuan menggunakan alat ukur dan sikap ilmiah

\begin{tabular}{lcc}
\hline & $\begin{array}{c}\text { Kemampuan } \\
\text { Menggunakan } \\
\text { Alat Ukur } \\
\text { Kategori Tinggi } \\
(\mathrm{B} 1)\end{array}$ & $\begin{array}{c}\text { Kemampuan } \\
\text { Menggunakan } \\
\text { Alat Ukur } \\
\text { Kategori Rendah } \\
(\mathrm{B} 2)\end{array}$ \\
& $\begin{array}{c}\mathrm{N} ; \bar{x} ; \text { SD; min; } \\
\text { maks) }\end{array}$ & $\begin{array}{c}\text { (N; } \bar{x} ; \text { SD; min; } \\
\text { maks })\end{array}$ \\
\hline Sikap & $14 ; 61,67 ; 8,35 ;$ & $12 ; 65,00 ; 11,24 ;$ \\
Ilmiah & 46,$67 ; 73,33$ & 40,$00 ; 83,33$ \\
Tinggi & & \\
\hline Sikap & $20 ; \quad 61,67 ;$ & $18 ; 60,74 ; 7,63 ;$ \\
Ilmiah & 13,$31 ; 40,00 ;$ & 50,$00 ; 73,33$ \\
Rendah & 90,00 & \\
\hline
\end{tabular}

\section{g. Hipotesis Ketujuh}

Hasil analisis data dengan anava sebelumnya menunjukkan bahwa $p$-value untuk hipotesis nol yang ketujuh $\left(\mathrm{H}_{0123}\right)$ sebesar 0,029. Hasil ini lebih kecil jika dibandingkan dengan nilai taraf signifikansi $\alpha$ yang telah ditetapkan sebelumnya, yakni sebesar 0,05 . Hal ini mnunjukkan bahwa hipotesis nol yang ketujuh $\left(\mathrm{H}_{0123}\right)$ ditolak, yang berarti ada interaksi antara metode pembelajaran dengan kemampuan menggunakan alat ukur dan sikap ilmiah siswa terhadap prestasi kognitif siswa. interaksi hanya terjadi pada kemampuan menggunakan alat ukur dengan sikap ilmiah siswa. Siswa dengan kemampuan menggunakan alat ukur kategori rendah memiliki sikap ilmiah yang lebih tinggi sedangkan siswa dengan kemampuan menggunakan alat 
ukur kategori tinggi tetap memiliki sikap ilmiah yang tinggi pula. Hal ini kemudian dapat dijadikan sebagai landasan bagi guru dalam melaksanakan proses pembelajaran di kelas untuk memperhatikan faktor kemampuan menggunakan alat ukur dan sikap ilmiah siswa dalam mempelajari sains, khususnya fisika, guna menunjang keberhasilan proses pembelajaran.

\section{Pembahasan Hasil Analisis Data Prestasi Afektif}

Uji hipotesis untuk data prestasi afektif tidak dapat dilakukan dengan uji anava sebagaimana halnya pada data prestasi kognitif. Perbedaan keduanya tidak akan mempengaruhi hasil penelitian. Hanya prosedur pengujiannya saja yang berbeda. Pada uji anava, penarikan keputusan didasarkan pada mean (rerata) kedua pihak yang dibandingkan sedangkan pada uji Kruskal-Wallis (statistik nonparametrik) lebih membandingkan pada median (nilai tengah) data.

Hasil uji Kruskal-Wallis untuk prestasi afektif yang dibandingkan terhadap metode pembelajaran diperoleh hasil bahwa kedua kelas tidak berbeda mediannya. Hal ini terbukti dari p-value hasil uji sebesar 0,368. P-value ini lebih besar jika dibandingkan dengan nilai taraf signifikansi $\alpha$ yang telah ditetapkan sebelumnya, yakni sebesar 0,05. Dengan demikian, hipotesis nol yang pertama $\left(\mathrm{H}_{01}\right)$ yang menyatakan bahwa tidak ada pengaruh penggunaan pendekatan PBL melalui metode eksperimen dan demonstrasi terhadap prestasi afektif siswa, tidak ditolak. Hal ini berarti bahwa antara metode pembelajaran eksperimen dan demonstrasi tidak memiliki pengaruh yang signifikan terhadap prestasi belajar siswa aspek afektif pada pokok bahasan hukum Hooke dan elastisitas. Kelas yang diberi pembelajaran dengan metode eksperimen memiliki nilai tengah sebesar
48,00 sedangkan kelas yang diberi pembelajaran dengan metode demonstrasi memiliki nilai tengah sebesar 49,00. Hal ini berarti bahwa tidak ada perbedaan yang signifikan nilai tengah prestasi afektif dari kedua kelompok tersebut.

Hasil uji statistik nonparametrik untuk prestasi afektif dengan faktor kemampuan menggunakan alat ukur diperoleh hasil p-value sebesar 0,726. Kelompok siswa dengan kemampuan menggunakan alat ukur kategori tinggi memiliki median (nilai tengah) prestasi afektif sebesar 49,00 sedangkan kelompok siswa dengan kemampuan menggunakan alat ukur kategori rendah memiliki nilai tengah prestasi afektif sebesar 48,00. Hal ini berarti bahwa kemampuan siswa dalam menggunakan alat ukur fisika tidak memberikan pengaruh yang berbeda terhadap prestasi afektifnya.

Pada faktor sikap ilmiah siswa, diperoleh hasil uji Kruskal-Wallis dengan $p$-value sebesar 0,084. Hasil ini lebih besar jika dibandingkan dengan nilai taraf signifikansi $\alpha$ yang telah ditetapkan sebelumnya, yakni sebesar 0,05 . Hal ini menunjukkan bahwa hipotesis nol yang ketiga $\left(\mathrm{H}_{03}\right)$ tidak ditolak, yang berarti tidak ada pengaruh sikap ilmiah tinggi dan sikap ilmiah rendah terhadap prestasi afektif siswa. Kelompok siswa dengan sikap ilmiah tinggi memiliki nilai tengah prestasi afektif sebesar 50,00 sedangkan kelompok siswa dengan sikap ilmiah rendah memiliki nilai tengah prestasi afektif sebesar 48,00. Karena nilai tengah prestasi afektif dari kedua kelompok siswa tersebut hampir sama maka hal ini berarti sikap ilmiah tinggi dan sikap ilmiah rendah tidak memberikan pengaruh yang signifikan terhadap prestasi afektif siswa. 
DAFTAR PUSTAKA

Bell, T., Urhahne, D., Schanze, S., \& Ploetzner, R. (2010).

Collaborative inquiry learning: Models, tools, and challenges. International journal of science education, 32(3), 349377.

de Jong, T., \& Lazonder, A. W. (2014). 15 The Guided Discovery Learning Principle in Multimedia Learning. The Cambridge handbook of multimedia learning, 371.

Pepper, C. (2008). Implementing problem based learning in a science faculty. Issues in Educational Research, 18(1), 6072.

Hung, W., Jonassen, D. H., \& Liu, R. (2008). Problem-based learning. Handbook of research on educational communications and technology, 3, 485-506.

Jonassen, D. H., \& Hung, W. (2008). All problems are not equal: Implications for problem-based learning. Interdisciplinary

Journal of Problem-Based Learning, 2(2), 4.

Kuhlthau, C. C., Maniotes, L. K., \& Caspari, A. K. (2015). Guided Inquiry: Learning in the 21st Century: Learning in the 21st Century. ABC-CLIO.

$\begin{array}{cr}\text { Suparno, P. (2007). } & \text { Metode } \\ \text { Pembelajaran } & \text { Fisika } \\ \text { Konstruktivistik } & \text { Dan } \\ \text { Menyenangkan. Universitas } & \\ \text { Sanata Dharma Yogyakarta. }\end{array}$

Dwijananti, P., \& Yulianti, D. (2010). Pengembangan kemampuan berpikir kritis mahasiswa melalui pembelajaran problem based instruction pada mata kuliah fisika lingkungan. Jurnal Pendidikan Fisika Indonesia, 6(2).

Hutagaol, K. (2013). Pembelajaran kontekstual untuk meningkatkan kemampuan representasi matematis siswa sekolah menengah pertama. Infinity Journal, 2(1), 85-99.

Saregar, A., Sunarno, W., \& Cari, C. (2013). Pembelajaran Fisika Kontekstual Melalui Metode Eksperimen Dan Demonstrasi Diskusi Menggunakan Multimedia Interaktif Ditinjau Dari Sikap Ilmiah Dan Kemampuan Verbal Siswa. Inkuiri, 2(02).

Walker, A., \& Leary, H. (2009). A problem based learning meta analysis: Differences across problem types, implementation types, disciplines, and assessment levels. Interdisciplinary Journal of Problem-based Learning, 3(1), 6.

Cahyono, W. D. (2007). Pengaruh Penggunaan Pendekatan Pembelajaran Berbasis Masalah Dengan Metode Demonstrasi dan Diskusi Terhadap Prestasi Belajar Fisika Ditinjau Dari Kreativitas Siswa. UNS: Tesis. 